\title{
Evaluation of Drip Irrigation System for Okra Crop under Tarai Condition of Uttarakhand, India
}

\author{
Ravish Chandra $^{1^{*}}$ and P.K. Singh ${ }^{2}$ \\ ${ }^{1}$ Dr. Rajendra Prasad Central Agricultural University, Pusa, Samastipur-848125, India \\ ${ }^{2}$ G.B. Pant University of Agriculture and Technology, Pantnagar, Uttarakhand, India \\ *Corresponding author
}

\section{Keywords \\ Distribution uniformity, Christiansen's uniformity Coefficient, Wilcox and Swails uniformity coefficient and hart uniformity coefficient \\ Article Info \\ Accepted: 04 February 2018 Available Online: 10 March 2018}

\section{A B S T R A C T}

Drip Irrigation Method is the best method that has been used in the world among the other irrigation methods because of its good and high uniformity. This method distributes water to the field using the pipe network and transforms it from the pipe network to the plant by emitters. A field experiment was conducted at experimental farm of college of Technology, G.B.P.U. A \& T, Pantnagar, Uttarakhand to evaluate the performance of drip irrigation system installed for okra crop. The different uniformity indicators were Distribution uniformity, Christiansen's uniformity coefficient (CUC), Wilcox and Swails uniformity coefficient and Hart Uniformity coefficient. The performance of the drip system under investigation can be categorised as good to excellent. The Distribution Uniformity, Christiansen's Uniformity Coefficient (CUC), Wilcox and Swails Uniformity Coefficient and Hart Uniformity Coefficient ranged from, 89.8 to 96.7, 92.4 to 97.8, 90.9 to 97.2 and 92.8 to 97.8 respectively. The highest crop yield for okra crop was reported in plot $\mathrm{T}_{1} \mathrm{R}_{3}$ (Drip irrigation based on $100 \%$ evaporation replenishment) which is having higher Distribution Uniformity, Christiansen Uniformity Coefficient, Wilcox and Swails Uniformity Coefficient and Hart Uniformity Coefficient values and lowest crop yield was reported in plot $T_{3} R_{2}$ (Drip irrigation based on $60 \%$ evaporation replenishment) having lowest DU, CUC, UCW and UCH values. The result clearly indicated that increase in irrigation uniformity increases the crop yield. Water production functions were developed for okra crop considering irrigation depth and spatial uniformity of water application under drip irrigation. The developed production functions can be used for predicting crop yield for different depth of irrigation and uniformity.

\section{Introduction}

Drip irrigation is an artificial method of supplying water to the roots of the plant. This system is at times called trickle irrigation system and includes trickling water onto the soil at low rates (2-20 liters/hour) from an arrangement of small measurement plastic funnels fitted with outlets called emitters or drippers. Drip Irrigation prevents soil erosion, saves water and fertilizer can also supplied by it. The high efficiency of drip irrigation results from two primary factors. The first is that the water soaks into the soil before it can evaporate or run off. The second is that the water is applied near plants so that only part of the soil in which the roots develop is wetted, not at all like surface and sprinkler irrigation, 
which includes wetting the entire soil profile. With drip irrigation system water, applications are more frequent (generally every 1-3 days) than with different techniques and this gives great high dampness level in the soil in which plants can flourish. Drip irrigation (also known as trickle irrigation, micro-irrigation, or low-volume irrigation) offers an excellent alternative to sprinkler irrigation for vegetable and small fruit growers. Trickle irrigation systems typically use 30-50 percent less water than sprinkler systems and the water are rationed to the plants as they need it. This reduces evaporation, grower to only water the desired plants and not the row alleys or roadways. Weed control is therefore simplified, and workers are able to do fieldwork while the irrigation system is running. The system's almost continuous operation at low flow rates and operating pressures allow the grower to irrigate with lower-cost, smaller pumps through smaller, lightweight pipes which may deliver as little as 15 or $20 \mathrm{~m} 3 / \mathrm{m}$.

Despite the success of drip irrigation systems in India and several part of the world, variety of problems related to optimal water and fertilizer management still remain. The theory behind trickle irrigation for conserving water and fertilizer is sound, but the implementation in the field may not always be practical. While the method has great potential for high irrigation efficiencies, poor system design, management, or maintenance, can lead to low efficiencies. In some instances the drip irrigation systems were installed with little concern for basic engineering hydraulic principles and resulted in non-uniform emitter discharge throughout the irrigated field. Irrigators in order to overcome this lack of uniformity found it necessary to over irrigate. Over irrigation can lead to the wastage of water, nutrients and energy as well as the possibility of ground water contamination due to excessive leaching. The crop yield is also affected by the spatial uniformity of water application. Keeping this in view the present study was undertaken to investigate the different uniformity indicators for drip irrigation and response of drip irrigation uniformity of water application on yield and water production functions.

\section{Materials and Methods}

The experiments were conducted at the experimental farm of the College of Technology, GBPUA and T, Pantnagar, at $24^{\circ} 43^{\prime} \mathrm{N}$ latitude, $46^{\circ} 43^{\prime} \mathrm{E}$ longitude and 635 $\mathrm{m}$ altitude. The experimental site was irrigated by a drip irrigation system. The field was further divided into nine plots. Before the start of the experiment, intact soil cores were collected from different locations in the field to determine soil physical properties including soil mechanical analysis. Locations were selected to represent the dominant soil conditions in the field.

The experimental site consists of sandy clay loam with sand (56\%), silt (16\%) and clay (28\%). The average bulk density of the experimental site was determined using core sampler. The average bulk density was found to be $1.50 \mathrm{~g} / \mathrm{cm}^{3}$. Drip irrigation system was installed for each plot. Buffer distances of approximately $1 \mathrm{~m}$ separated the plots to reduce environmental influences between them. Drip system (DI) was equipped with controllers to control the pressure and flow meter to quantify the water added in each irrigation event. Each plot was approximately $4 \mathrm{~m}$ wide and $6 \mathrm{~m}$ long and had 8 rows of drip lines spaced $0.5 \mathrm{~m}$ apart running from west to east. The DI system consisted of $16 \mathrm{~mm}$ inside diameter (I.D.) thin-wall drip lines with welded-on emitters (GR, $50 \mathrm{~cm}$ dripper spacing) with a nominal emitter discharge of 4 $\mathrm{L} / \mathrm{h}$ at a design pressure of $200 \mathrm{kPa}$. Irrigation amounts were metered separately in each plant. The irrigation time varied between 
treatments because of the three different methods of irrigation scheduling used. The hydraulic aspects of the design for drip system aimed to obtain uniform application of irrigation water. The water application uniformity is a measure of how evenly the volumes of water are applied from each emitter. This uniformity was determined by measuring emitter flow rates by measuring the volume of water filled in a container in 30 minutes. To measure emitter flow rates, graduated cylinder was used to measure the volume collected for a given time of 30 minutes. A stop watch was used to measure times. Altogether 15 samples were taken from each experimental plot. A total of 135 measurements were taken from the nine plots. The crop planted in the field was okra. The variety of the crop was US $7109 \mathrm{~F}_{1}$ hybrid. The treatment details of experiment are presented below.

$\mathrm{T}_{1}-100 \%$ level of estimated crop water requirement through drip irrigation

$\mathrm{T}_{2}-80 \%$ level of estimated crop water requirement through drip irrigation

$\mathrm{T}_{3}-60 \%$ level of estimated crop water requirement through drip irrigation

The evaluations of water application uniformity in this study were calculated with the following methods. First, the uniformity of water applied from the drip irrigation system using discharge measurement data from emitters and the following equations were used to evaluate the drip system.

\section{Christiansen uniformity coefficient}

Christiansen's uniformity coefficient (CUC) is the most commonly used statistical method for evaluating sprinkler system uniformity (Warrick, 1983). Christiansen's uniformity is defined as:

$$
100\left(1-\frac{\Delta \bar{y}}{\bar{y}}\right)
$$

Where,

CUC $=$ Uniformity coefficient percentage, $\Delta \bar{y}$ $=$ absolute value of the mean deviation of irrigation depth, and $\Delta \bar{y}=$ mean depth of irrigation (Christiansen 1942). By substituting emmiter flow rate $\mathrm{q}_{\mathrm{e}}$ for $\mathrm{y}$, the uniformity for trickle irrigation lateral lines can be estimated.

\section{Distribution uniformity}

Merriam and keller (1978) suggested a new parameter as distribution uniformity. Distribution uniformity is expressed as a percentage, and is a relative index of the variability between emitters in an irrigation block. Distribution uniformity is defined as the average discharge of $25 \%$ of the sampled emitters with the least discharge, divided by the average discharge of all sampled emitters.

\section{Wilcox-Swailes uniformity coefficient}

The uniformity of sprinkler irrigation can also be described using common statistical parameters such as the coefficient of variation $\left(\mathrm{V}_{\mathrm{y}}\right)$ of the depth of irrigation water, $\mathrm{y}$ (Wilcox - Swailes, 1947). The statistical uniformity coefficient is defined as

$$
U C W=100\left(1-V_{y}\right)=100\left(1-\frac{s_{y}}{\bar{y}}\right)(2)
$$

Where,

$\mathrm{UCW}=$ statistical uniformity coefficient as a percentage, and $\mathrm{V}_{\mathrm{y}}=$ coefficient of variation of the depth of irrigation water, $\bar{y}$, or as the previously defined the standard deviation $\left(S_{y}\right)$ over the mean $\bar{y}$. A similar statistical approach can be developed for trickle irrigation systems where the random variable $\mathrm{y}$, the depth of water in sprinkler irrigation is replaced by q so 
that equation 3.13 becomes

$U C W=100\left(1-V_{q}\right)=100\left(1-\frac{s_{q}}{\bar{q}}\right)$

\section{Hawlin Sugar Planters Association- UCH (Hart, 1961)}

If the distribution in the field is normal, then the absolute mean deviation from the mean is equal to $\sqrt{2 / \pi S=0.798 S}$. The Hart proposes the following uniformity coefficient.

$U C H=100\left(1-\frac{0.7985}{\bar{y}}\right)$

\section{Results and Discussion}

Despite the success of drip irrigation systems in India and several part of the world, variety of problems related to optimal water and fertilizer management still remain. The theory behind trickle irrigation for conserving water and fertilizer is sound, but the implementation in the field may not always be practical. While the method has great potential for high irrigation efficiencies, poor system design, management, or maintenance, can lead to low efficiencies. In some instances the drip irrigation systems were installed with little concern for basic engineering hydraulic principles and resulted in non-uniform emmiter discharge throughout the irrigated field. Irrigators in order to overcome this lack of uniformity found it necessary to over irrigate. Over irrigation can lead to the wastage of water, nutrients and energy as well as the possibility of ground water contamination due to excessive leaching. The crop yield is also affected by the spatial uniformity of water application. In order to achieve this, the uniformity with which the irrigation system applies water will have to be high. The distribution uniformity of a system has an effect on the system's application efficiency and on the crop yield (Letey et al.,
Solomon, Letey and Solomon). Irrigation systems with poor distribution uniformity experience reduced yields due to water stress and/or water logging (Solomon and Clemmens and Solomon. Poor distribution uniformity also has increased financial and environmental costs. Keeping this in view the present study was undertaken to investigate the different uniformity indicators and response of drip irrigation uniformity of water application on yield and water production functions.

\section{Uniformity of water application}

The uniformity evaluation results for the water applied by the drip system were determined and presented in Table 1. The parameters relating to the performance of drip irrigation system during the okra experiment are presented in Table 1. The overall distribution efficiency of the system ranged from 89.80 to 96.70 percent which can be categorised as excellent since DU values were upto or equal 90 percent (Schuebach et al., 1999). The highest distribution uniformity was obtained in plot $\mathrm{T}_{2} \mathrm{R}_{1}$ (Drip irrigation based on $80 \%$ evaporation replenishment) while the lowest value of distribution uniformity (DU) was obtained in plot number $\mathrm{T}_{3} \mathrm{R}_{2}$ (Drip irrigation based on $60 \%$ evaporation replenishment). The difference between the highest and lowest distribution efficiency value was 7.6 percent.

The overall Christiansen uniformity coefficient (CUC) of the system ranged between 92.36 to 97.85 percent which can be categorised as an excellent. The highest uniformity coefficient was obtained in plot $\mathrm{T}_{2} \mathrm{R}_{1}$ (Drip irrigation based on $80 \%$ evaporation replenishment) while, the lowest value was obtained in plot $\mathrm{T}_{3} \mathrm{R}_{2}$ (Drip irrigation based on $60 \%$ evaporation replenishment). The difference between the highest and lowest uniformity coefficient was 5.94 percent. 
Table.1 Performance of irrigation system in terms of different uniformity indicators during okra crop

\begin{tabular}{|c|c|c|c|c|c|c|}
\hline $\begin{array}{c}\text { Plot } \\
\text { no. }\end{array}$ & $\begin{array}{l}\text { Crop } \\
\text { yield } \\
\text { (t/ha) }\end{array}$ & $\begin{array}{l}\text { Depth of } \\
\text { irrigation } \\
\quad(\mathrm{mm})\end{array}$ & $\begin{array}{l}\text { Christiansen } \\
\text { uniformity } \\
\text { coefficient - } \\
\text { CUC }\end{array}$ & $\begin{array}{c}\text { Distribution } \\
\text { uniformity - } \\
\text { DU }\end{array}$ & $\begin{array}{c}\text { Wilcox and } \\
\text { Swails - } \\
\text { UCW }\end{array}$ & $\begin{array}{c}\text { Hart } \\
\text { Uniformity } \\
\text { coefficient- } \\
\text { UCH }\end{array}$ \\
\hline $\mathbf{T}_{1} \mathbf{R}_{1}$ & 9.80 & 361 & 96.95 & 96.20 & 94.90 & 95.97 \\
\hline $\mathbf{T}_{1} \mathbf{R}_{2}$ & 10.71 & 361 & 97.45 & 95.80 & 95.34 & 96.33 \\
\hline $\mathbf{T}_{1} \mathbf{R}_{3}$ & 11.41 & 361 & 97.60 & 96.30 & 96.19 & 96.99 \\
\hline $\mathbf{T}_{2} \mathbf{R}_{1}$ & 9.90 & 291 & 97.85 & 96.70 & 97.20 & 97.79 \\
\hline $\mathbf{T}_{2} \mathbf{R}_{2}$ & 10.06 & 291 & 97.21 & 96.50 & 96.45 & 97.19 \\
\hline $\mathbf{T}_{\mathbf{2}} \mathbf{R}_{\mathbf{3}}$ & 11.22 & 291 & 95.94 & 94.40 & 92.86 & 94.36 \\
\hline $\mathbf{T}_{3} \mathbf{R}_{1}$ & 8.19 & 222 & 92.96 & 93.40 & 94.48 & 95.64 \\
\hline $\mathbf{T}_{3} \mathbf{R}_{2}$ & 7.55 & 222 & 92.36 & 89.80 & 90.86 & 92.79 \\
\hline $\mathbf{T}_{3} \mathbf{R}_{3}$ & 8.13 & 222 & 94.60 & 92.40 & 92.77 & 94.29 \\
\hline
\end{tabular}

Table.2 Crop water production function based on irrigation depth and uniformity for okra

\begin{tabular}{|c|c|c|c|}
\hline S.N. & $\begin{array}{l}\text { Uniformity } \\
\text { Coefficient }\end{array}$ & $\begin{array}{c}\text { Crop Water Production } \\
\text { Function }\end{array}$ & Remark \\
\hline 1. & $\begin{array}{l}\text { Christiansen } \\
\text { Uniformity Coefficient } \\
\text { (CUC) }\end{array}$ & $\begin{array}{l}\mathrm{Y}=0.005 \mathrm{DI}+0.47 \mathrm{CUC}-36.4 \\
\text { Multiple R- } 0.89 \\
\text { Standard Error- } 0.72\end{array}$ & $\begin{array}{l}\text { Y = Crop yield } \\
\text { DI = Depth of irrigation, mm } \\
\text { CUC = Christiansen } \\
\text { uniformity coefficient, } \%\end{array}$ \\
\hline 2. & $\begin{array}{l}\text { Distribution } \\
\text { Uniformity (DU) }\end{array}$ & $\begin{array}{l}\mathrm{Y}=0.06 \mathrm{DI}+0.18 \mathrm{DU}-9.8 \\
\text { Multiple R- } 0.86 \\
\text { Standard Error- } 0.82\end{array}$ & $\begin{array}{l}\mathrm{Y}=\text { Crop yield } \\
\mathrm{DI}=\text { Depth of irrigation, mm } \\
\mathrm{DU}=\text { Distribution uniformity, } \\
\%\end{array}$ \\
\hline 3. & $\begin{array}{l}\text { Wilcox and Swails } \\
\text { Uniformity Coefficient } \\
\text { (UCW) }\end{array}$ & $\begin{array}{l}\mathrm{Y}=0.016 \mathrm{DI}+0.15 \mathrm{UCW}-9.1 \\
\text { Multiple R- } 0.83 \\
\text { Standard Error- } 0.91\end{array}$ & $\begin{array}{l}\text { Y = Crop yield } \\
\text { DI = Depth of irrigation, mm } \\
\text { UCW = Wilcox and Swails } \\
\text { uniformity coefficient, } \%\end{array}$ \\
\hline 4. & $\begin{array}{l}\text { Hart Uniformity } \\
\text { Coefficient (UCH) }\end{array}$ & $\begin{array}{l}\mathrm{Y}=0.016 \mathrm{DI}+0.19 \mathrm{UCH}-13.1 \\
\text { Multiple R- } 0.83 \\
\text { Standard Error-0.91 }\end{array}$ & $\begin{array}{l}\mathrm{Y}=\text { Crop yield } \\
\mathrm{DI}=\text { Depth of irrigation, } \mathrm{mm} \\
\mathrm{UCH}=\text { Hart uniformity } \\
\text { coefficient, } \%\end{array}$ \\
\hline
\end{tabular}

Wilcox and Swailes replaced the absolute mean deviation from the mean, with the standard deviation. Wilcox and Swailes uniformity of the system ranged from 90.86 to 97.20 percent, which can be categorised as excellent. The highest uniformity was obtained in plot number $\mathrm{T}_{2} \mathrm{R}_{1}$ (Drip irrigation based on $80 \%$ evaporation replenishment) while, the lowest value of distribution uniformity (DU) was obtained in plot number $\mathrm{T}_{3} \mathrm{R}_{2}$ (Drip irrigation based on $60 \%$ evaporation replenishment). The difference between the highest and lowest Wilcox Swails uniformity coefficient was 6.97 percent. 
Hart uniformity coefficient of the system ranged from 92.79 to 97.80 , which can be categorised as an excellent. The highest uniformity was obtained in plot number $\mathrm{T}_{2} \mathrm{R}_{1}$ (Drip irrigation based on $80 \%$ evaporation replenishment) while, the lowest value of distribution uniformity (DU) was obtained in plot number $\mathrm{T}_{3} \mathrm{R}_{2}$ (Drip irrigation based on $60 \%$ evaporation replenishment). The difference between the highest and lowest Wilcox Swails uniformity coefficient was 5.38 percent. The findings obtained in the study was in agreement with the other researchers (Camp et al., 1997, Al-Ghobari et al., 2013 and Mistry et al., 2017)

In general, results indicated that the design and management of an irrigation system are not the only factors that influence water uniformity above soil surface for any irrigation system. Therefore, other factors should be taking into consideration, such as, the hydraulic gradients existing within the unevenly wetted soil which influence water movement laterally and perpendicularly within the root zone

\section{Yield as affected by depth of water applied and uniformity}

The highest crop yield for okra crop was reported in plot $T_{1} R_{3}$ (Drip irrigation based on $100 \%$ evaporation replenishment) which is having higher DU, CUC, UCW and $\mathrm{UCH}$ values and lowest crop yield was reported in plot $T_{3} R_{2}$ (Drip irrigation based on $60 \%$ evaporation replenishment) having lowest DU, CUC, UCW and UCH values. The result clearly indicates that increase in irrigation uniformity increases the crop yield.

The uniformity of water application from drip irrigation system may have been affected by water pressure distribution in the pipe network and hydraulic properties of emitters used. The relatively lower value of DU, CUC,
UCW and UCH in treatment $\mathrm{T}_{3}$ may be due to emitter plugging or due to manufacturing variation among treatments (Manjunath et al., 1998).

\section{Crop water production functions based on irrigation depth and uniformity}

Water production functions have been developed for okra crop considering irrigation depth and spatial uniformity of water application under drip irrigation. Crop water production functions considering irrigation depth and different uniformity coefficients for okra is presented in Table 2. The multiple regression equations were also developed for okra crop considering crop yield as dependent variable and depth of irrigation and coefficient of uniformity as independent variable. The important multiple regression statistics such as multiple correlation coefficient (Multiple R) and standard error was obtained as 0.89 and 0.72 respectively.

On the similar lines multiple regression equation was also developed considering okra crop yield as dependent variable and depth of irrigation and distribution uniformity as independent variable. The multiple regression statistics such as multiple correlation coefficient (Multiple R) and standard error was found to be 0.86 and 0.82 respectively.

The empirical relation developed considering okra crop yield as dependent parameter and depth of irrigation and Wilcox and Swails uniformity coefficients as independent parameter is presented in Table 2. The multiple regression statistics such as multiple correlation coefficients was 0.83 and standard error was 0.91 .

The crop water production function developed considering okra crop yield as dependent parameter and depth of irrigation and Hart uniformity coefficient as independent 
parameter is presented in Table 2. The multiple regression statistics such as multiple correlation coefficients was 0.83 and standard error was 0.91 .

The developed production functions can be used for predicting crop yield for different depth of irrigation and uniformity. The results show that the optimum irrigation amount depends on irrigation uniformity and on agronomic and economic factors. Matovani et al., (1995) found the similar results. For fixed uniformity coefficient and uniformity, the optimum amount of irrigation amount can be determined.

The uniformity of water application is the key in evaluation of drip irrigation system. The performance of the drip irrigation system was evaluated with the different standard uniformity indicators of drip system. The performance of the drip system under investigation can be categorised as good to excellent. The Distribution uniformity, Christiansen's uniformity coefficient (CUC), Wilcox and Swails uniformity coefficient and Hart Uniformity coefficient ranged from, 89.8 to $96.7,92.4$ to $97.8,90.9$ to 97.2 and 92.8 to 97.8 respectively. The highest crop yield for okra crop was reported in plot $\mathrm{T}_{1} \mathrm{R}_{3}$ (Drip irrigation based on $100 \%$ evaporation replenishment) which is having higher DU, CUC, UCW and UCH values and lowest crop yield was reported in plot $\mathrm{T}_{3} \mathrm{R}_{2}$ (Drip irrigation based on $60 \%$ evaporation replenishment) having lowest DU, CUC, $\mathrm{UCW}$ and $\mathrm{UCH}$ values. The result clearly indicates that increase in irrigation uniformity increases the crop yield. Water production functions were developed for okra crop considering irrigation depth and spatial uniformity of water application under drip irrigation. The developed production functions can be used for predicting crop yield for different depth of irrigation and uniformity. The derived equation may provide useful guide to the potential performance of the drip irrigation scheduling techniques.

\section{References}

Al-Ghobari, H. M. 2012. A comparison of water application uniformity for drip irrigation system above and below soil surface at various soil depths and scheduling techniques in arid region. Transactions of Ecology and The Environment. 68: pp311-321

Camp, C.R., Bauer, B.J., and Busscher, W.J. 1997. A comparison of uniformity measures for drip irrigation. Transactions of the ASAE 40(4): pp. 1013-1020.

Clemmens A. J and Solomon K. H 1997. Estimation of global irrigation distribution uniformity. J. Irrig. Drain. Eng. 123 (6) pp. 454-461.

Hart W.E. 1961. Overhead irrigation pattern parameters. Agric. Eng. 42(7):355-356.

Letey, 1985. Irrigation uniformity as related to optimum crop production- Additional research is needed. Irrig. Sci. (6) pp. 253-263.

Letey, J., Vaux, H. J. and Feinerman, N. 1984. Optimum crop water applications as affected by uniformity of water infiltration. Agron. J. 76: pp. 435-441.

Manjunath, M.V. 1998. Studies on testing and applicability of microirrigation and other irrigation systems in sweetlime intercropping. Ph. D. Thesis, GBPUA, Pantnagar, pp 273.

Mantovani, E.C., Vilalobus, F.J., Orgaz, F. and Fereres, E. 1995. Modelling the effects of sprinkler irrigation uniformity on crop yield, Agriculture Water Management, 27: 243-257.

Merriam, J. L. and Keller, J. 1978. Farm irrigation system evaluation: a guide for management. Utah State University, Logan, UT, 271 pp. 255 
Mistry, P., Akil, M., Suryanaryana, T.M.V. and Parekh, F. P. 2017. Evaluation of drip irrigation system for different operating pressure. International Journal of Advance Engineering and Research Development 2: pp 2348-4470

Schulbach, K., Tjosvold, S., Kasapligi, D. 1999. Improving irrigation system conserves water in greenhouse grown cut flowes. Calif. Agric., 53 (2): 44-48.

Solomon, K. H. 1983. Irrigation Uniformity and Yield Theory. Ph.D. thesis, Utah State University, Utah State University, Logan, USA.

Solomon, K. H. 1984. Yield related interpretations of irrigation uniformity and efficiency measures. Irrig. Sci. (5) pp. 161-172.

Solomon, K. H. 1990. Sprinkler irrigation uniformity. [Internet]. Centre for Irrigation Technology, California State University, Fresno, USA. Available from: <http://www.wateright.org/site/ publications /900803.html

Warrick, A.W. 1983. Interrelationships of Irrigation Terms. Journal of Irrigation and Drainage Engineering. 109(3):317332

Wilcox, J.C. and Swailes, G.E. 1947. Uniformity of water distribution by some undertree orchards sprinklers. Scientific Agric. 27: 565-583

\section{How to cite this article:}

Ravish Chandra and Singh, P.K. 2018. Evaluation of Drip Irrigation System for Okra Crop under Tarai Condition of Uttarakhand, India. Int.J.Curr.Microbiol.App.Sci. 7(03): 132-139. doi: https://doi.org/10.20546/ijcmas.2018.703.015 